\title{
Use of Pt and Boron-Doped Diamond Anodes in the Electrochemical Advanced Oxidation of Ponceau SS Diazo Dye in Acidic Sulfate Medium
}

\author{
Alexsandro Jhones dos Santos, ${ }^{[b]}$ Carlos A. Martínez-Huitle ${ }^{[b]}$ Ignasi Sirés, ${ }^{[a]}$ and Enric Brillas ${ }^{*[a]}$
}

The electrochemical degradation of $2.5 \mathrm{~L}$ of Ponceau SS diazo dye solution in acidic sulfate medium has been studied in a prepilot flow plant with a boron-doped diamond (BDD)/airdiffusion or Pt/air-diffusion cell connected to an annular photoreactor. The decolorization and mineralization was enhanced in the order: electrochemical oxidation with electrogenerated $\mathrm{H}_{2} \mathrm{O}_{2}<$ electro-Fenton < photoelectro-Fenton. The two former methods performed better with the BDD anode, whereas the latter yielded similar results for both anodes. From this, the use of less expensive active anodes such as Ti|Pt instead of nonactive BDD for photo-assisted Fenton-based electrochemical processes is recommended. In all methods, increasing current density led to a greater degradation rate, but with lower mineralization current efficiency and higher energy consumption. Five primary aromatic products and four final carboxylic acids were detected, along with recalcitrant products poorly removed by hydroxyl radicals and UVA radiation.

\section{Introduction}

Acid azo dyes are mainly utilized in textile industries for dyeing of natural (silk, cotton, wool) and synthetic (rayon, acrylic, polyester) fibers. ${ }^{[1-4]}$ They can also be used in leather, plastics, inks, and paints. These dyes are characterized by a high solubility in water because the azo group is linked to aromatic rings containing $-\mathrm{SO}_{3}{ }^{-}$groups. ${ }^{[1,4]}$ All around the world, a high number of industries discharges large volumes of wastewater containing up to $250 \mathrm{mg} \mathrm{L}^{-1}$ of dyes into the aquatic environment, causing a considerable impact in water bodies due to their increase in color and limited light penetration. ${ }^{[5]}$ Moreover, acid azo dyes and their by-products present a large resistance to biodegradation and can cause negative effects to living beings, such as mutagenicity, carcinogenicity, and toxicity. ${ }^{[6-9]}$ This is the case of Ponceau SS or Acid Red 150 (characteristics shown in Table 1), also employed as stain in biomedical applications, including hematology and histology. It has been documented that Ponceau SS is irritant to eyes and may alter lung functions giving rise to pneumoconiosis. Despite all these concerns, no previous work dealing with the removal of this diazo dye from wastewater has been reported yet.

Several electrochemical technologies ${ }^{[3,4]}$ have shown larger ability for the remediation of water contaminated with azo dyes than classical technologies such as filtration, ${ }^{[7]}$ adsorption, ${ }^{[10]}$

[a] Prof. I. Sirés, Prof. E. Brillas

Departament de Química Física

Facultat de Química, Universitat de Barcelona

Martí i Franquès 1-11, 08028 Barcelona, Spain

E-mail: brillas@ub.edu

[b] A. J. dos Santos, Prof. C. A. Martínez-Huitle Instituto de Química

Universidade Federal do Rio Grande do Norte Lagoa Nova - CEP 59.072-900, RN, Brazil

Supporting information for this article is available on the WWW under https://doi.org/10.1002/celc.201701238

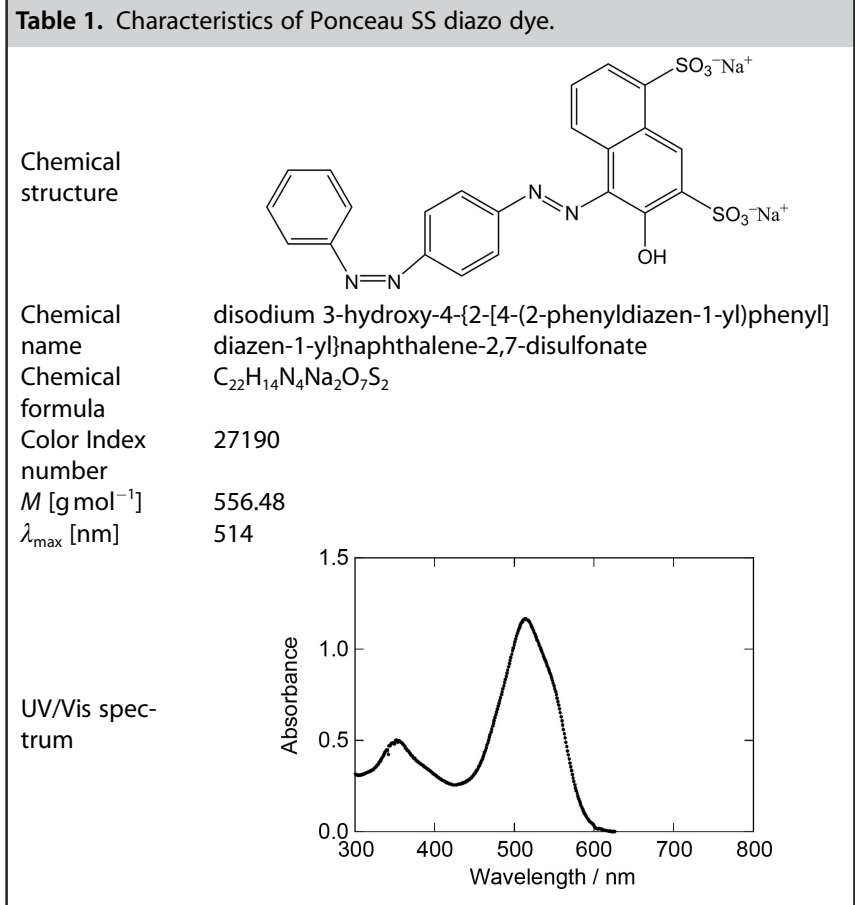

and coagulation. ${ }^{[10,11]}$ Electrocoagulation is one of the most typical electrochemical methods, in which a fraction of pollutants and their oxidation products can be coagulated with $\mathrm{Fe}(\mathrm{OH})_{n}$ or $\mathrm{Al}(\mathrm{OH})_{3}$ flocs originated from oxidation of sacrificial Fe or Al anodes, respectively. Nevertheless, this is mainly a phase separation method since organics are transferred to the sludge formed, which needs post-treatment. ${ }^{[3]}$ More appropriate technologies for azo dyes removal are the electrochemical advanced oxidation processes (EAOPs), which involve the destruction of organics up to mineralization by the attack of reactive oxygen species (ROS) generated on site, like the strong 
oxidant ${ }^{\circ} \mathrm{OH} .{ }^{[4,11-15]}$ In all the EAOPs, water oxidation at the anode $M$ produces physisorbed $\mathrm{M}\left({ }^{\circ} \mathrm{OH}\right)$ at high current by reaction (1) that attacks organic pollutants. ${ }^{[11,16-18]}$ In anodic oxidation ( $\mathrm{AO}$ ), this is the only oxidant. If an adequate cathode to produce $\mathrm{H}_{2} \mathrm{O}_{2}$ by reduction of injected $\mathrm{O}_{2}$ from reaction (2) is used as counterpart, the process is so-called $\mathrm{AO}$ with electrogenerated $\mathrm{H}_{2} \mathrm{O}_{2}\left(\mathrm{AO}-\mathrm{H}_{2} \mathrm{O}_{2}\right)$ and organics are not only attacked by $\mathrm{M}\left({ }^{\circ} \mathrm{OH}\right)$, but also by weaker oxidants like $\mathrm{H}_{2} \mathrm{O}_{2}$ and its anodic oxidation product, hydroperoxyl radical $\left(\mathrm{HO}_{2}{ }^{\circ}\right) \cdot{ }^{[15,19]}$

$\mathrm{M}+\mathrm{H}_{2} \mathrm{O} \rightarrow \mathrm{M}\left({ }^{\circ} \mathrm{OH}\right)+\mathrm{H}^{+}+\mathrm{e}^{-}$

$\mathrm{O}_{2(\mathrm{~g})}+2 \mathrm{H}^{+}+2 \mathrm{e}^{-} \rightarrow \mathrm{H}_{2} \mathrm{O}_{2}$

Good efficiencies for reaction (2) have been found by employing carbonaceous cathodes. Among them, materials such as graphite, ${ }^{[20]}$ graphite felt, ${ }^{[21]}$ carbon sponge, ${ }^{[22]}$ carbon felt, ${ }^{[21,23-25]}$ carbon nanotubes, ${ }^{[26,27]}$ and carbon-polytetrafluoroethylene (PTFE) air-diffusion ${ }^{[28-30]}$ electrodes have been utilized. On the other hand, it is well known that the anode material has remarkable influence on the oxidation power of $\mathrm{AO}$ and $\mathrm{AO}$ $\mathrm{H}_{2} \mathrm{O}_{2} \cdot{ }^{[4,18,21]}$ An active anode like $\mathrm{Pt}$ produces low amounts of reactive $\mathrm{Pt}\left({ }^{\circ} \mathrm{OH}\right)$ from reaction (1) because the strong $\mathrm{Pt}-{ }^{\circ} \mathrm{OH}$ interaction and low $\mathrm{O}_{2}$-evolution overpotential facilitates its oxidation to yield the weaker "chemisorbed" $\mathrm{PtO}_{\mathrm{x}}$ species, which favors the electrochemical conversion of organics into carboxylic acids. ${ }^{[21,31]}$ The opposite behavior is accomplished for a non-active anode such as boron-doped diamond (BDD), in which organics become incinerated to $\mathrm{CO}_{2}$ due to the high quantities of reactive $\mathrm{BDD}\left({ }^{\circ} \mathrm{OH}\right)$ produced because of the larger overpotential required for $\mathrm{O}_{2}$ evolution along with the very weak BDD- ${ }^{-} \mathrm{OH}$ interaction. ${ }^{[31-33]}$ At present, the BDD anode is considered the best material for these methods.

Recently, Fenton-based EAOPs have shown larger ability to remove azo dyes from wastewater. ${ }^{[28,29,34,35]}$ In these processes, cathodically generated $\mathrm{H}_{2} \mathrm{O}_{2}$ is catalytically converted into ${ }^{\circ} \mathrm{OH}$ by Fenton's reaction (3) upon the action of a small concentration of added $\mathrm{Fe}^{2+} \cdot{ }^{[36-38]}$ This occurs in the electro-Fenton (EF) method, where $\mathrm{M}\left({ }^{\circ} \mathrm{OH}\right)$ and ${ }^{\bullet} \mathrm{OH}$ are the main oxidants, with optimum $\mathrm{pH}$ near $3 .^{[28,33,37]}$ Reduction of $\mathrm{Fe}^{3+}$ to $\mathrm{Fe}^{2+}$ at the cathode propagates Fenton's reaction (3). ${ }^{[15,37,38]}$ A modification of EF is photoelectro-Fenton (PEF), which involves the illumination of treated solution with UVA light. ${ }^{[4,39]}$ This light can cause the quick photolysis of some products such as $\mathrm{Fe}(\mathrm{OH})^{2+}$ by reaction (4), enhancing $\mathrm{Fe}^{2+}$ and ${ }^{\bullet} \mathrm{OH}$ production, along with that of final carboxylic acids via reaction (5). ${ }^{[40,41]}$ When natural sunlight is utilized as free energy source, the process is socalled solar PEF (SPEF), which is much more cost-effective for wastewater treatment. ${ }^{[29,42,43]}$

$$
\begin{aligned}
& \mathrm{Fe}^{2}+\mathrm{H}_{2} \mathrm{O}_{2} \rightarrow \mathrm{Fe}^{3+}+{ }^{\cdot} \mathrm{OH}+\mathrm{OH}^{-} \\
& \mathrm{Fe}(\mathrm{OH})^{2+}+h v \rightarrow \mathrm{Fe}^{2+}+{ }^{\cdot} \mathrm{OH} \\
& \mathrm{Fe}(\mathrm{OOCR})^{2+}+h v \rightarrow \mathrm{Fe}^{2+}+\mathrm{CO}_{2}+\mathrm{R}^{\cdot}
\end{aligned}
$$

A limited number of papers has shown that the influence of the anode (active and non-active) over the performance of photo-assisted Fenton-based EAOPs to degrade organics is small because of the powerful photolytic action of UV radiation. ${ }^{[30,44]}$ This differs from the results found for the $A O$ process, where the non-active BDD anode presents much greater oxidation ability than the active ones. More research efforts are required to know if such behavior is also verified during the degradation of acid azo dyes since this represents a key factor for the viability and scale-up of the EAOPs at industrial scale.

This work presents a study on the decolorization and mineralization of Ponceau SS diazo dye solutions in acidic sulfate medium by means of $\mathrm{AO}-\mathrm{H}_{2} \mathrm{O}_{2}, \mathrm{EF}$, and PEF. The assays were made in a $2.5 \mathrm{~L}$ pre-pilot flow plant as a first approach, allowing the determination of the current efficiency and energy consumption. Aiming to clarify the role of the anode in each EAOP, an active $\mathrm{Ti} \mid \mathrm{Pt}$ and a non-active BDD were used under comparable conditions. $\mathrm{H}_{2} \mathrm{O}_{2}$ was always supplied by a carbonPTFE air-diffusion electrode. The effect of current density (j) on the performance of each process was examined. Gas chromatography-mass spectrometry (GC-MS) and high-performance liquid chromatography (HPLC) were utilized to detect the primary aromatic intermediates and final carboxylic acids, respectively.

\section{Results and Discussion}

\subsection{Degradation of Ponceau SS using a Pt Anode}

First, the ability of the pre-pilot flow plant to generate $\mathrm{H}_{2} \mathrm{O}_{2}$ with a Pt/air-diffusion cell was tested using $0.050 \mathrm{M} \mathrm{Na}_{2} \mathrm{SO}_{4}$ as background electrolyte at $\mathrm{pH} 3.0,35{ }^{\circ} \mathrm{C}$ and $j=50 \mathrm{mAcm}^{-2}$. Under these $\mathrm{AO}-\mathrm{H}_{2} \mathrm{O}_{2}$ conditions, $15.1 \mathrm{mM} \mathrm{H} \mathrm{O}_{2}$ (33.8\% efficiency) were accumulated at $360 \mathrm{~min}$. The efficiency decreased over time, which can be ascribed to the anodic oxidation of this species to $\mathrm{O}_{2}$ via $\mathrm{HO}_{2}{ }^{\bullet}$ as intermediate. ${ }^{[4,15]}$ In the presence of $0.50 \mathrm{mM} \mathrm{Fe}^{2+}$ (EF conditions), a greater $\mathrm{H}_{2} \mathrm{O}_{2}$ decay was found, only achieving $4.3 \mathrm{mM}$ by the concurrence of Fenton's reaction (3). When the solution was recirculated through the annular photoreactor containing a $160 \mathrm{~W}$ UVA lamp (PEF conditions), the drop of accumulated $\mathrm{H}_{2} \mathrm{O}_{2}$ was more pronounced, attaining $1.5 \mathrm{mM}$ at $360 \mathrm{~min}$, due to the acceleration of Fenton's reaction (3) induced by the photolytic reaction (4). These findings show that the amount of $\mathrm{H}_{2} \mathrm{O}_{2}$ generated in both Fenton-based EAOPs was high enough for maximum ${ }^{\circ} \mathrm{OH}$ production.

Then, solutions with $0.19 \mathrm{mM}$ Ponceau SS $\left(50 \mathrm{mg} \mathrm{L}^{-1}\right.$ of total organic carbon (TOC)) were prepared under the above conditions to be degraded by $\mathrm{AO}-\mathrm{H}_{2} \mathrm{O}_{2}, \mathrm{EF}$ and PEF at $j$ values of 25, 50, and $100 \mathrm{mAcm}^{-2}$ for $360 \mathrm{~min}$ in order to examine the role of oxidants. In $\mathrm{EF}$ and $\mathrm{PEF}$, a catalytic concentration $0.50 \mathrm{mM}$ of $\mathrm{Fe}^{2+}$ was added as optimal quantity. ${ }^{[41-43]} \mathrm{A}$ little change in solution $\mathrm{pH}$ was found in all these trials, showing a slight decrease to final $\mathrm{pH} 2.7-2.8$ due to the formation of acidic by-products. 

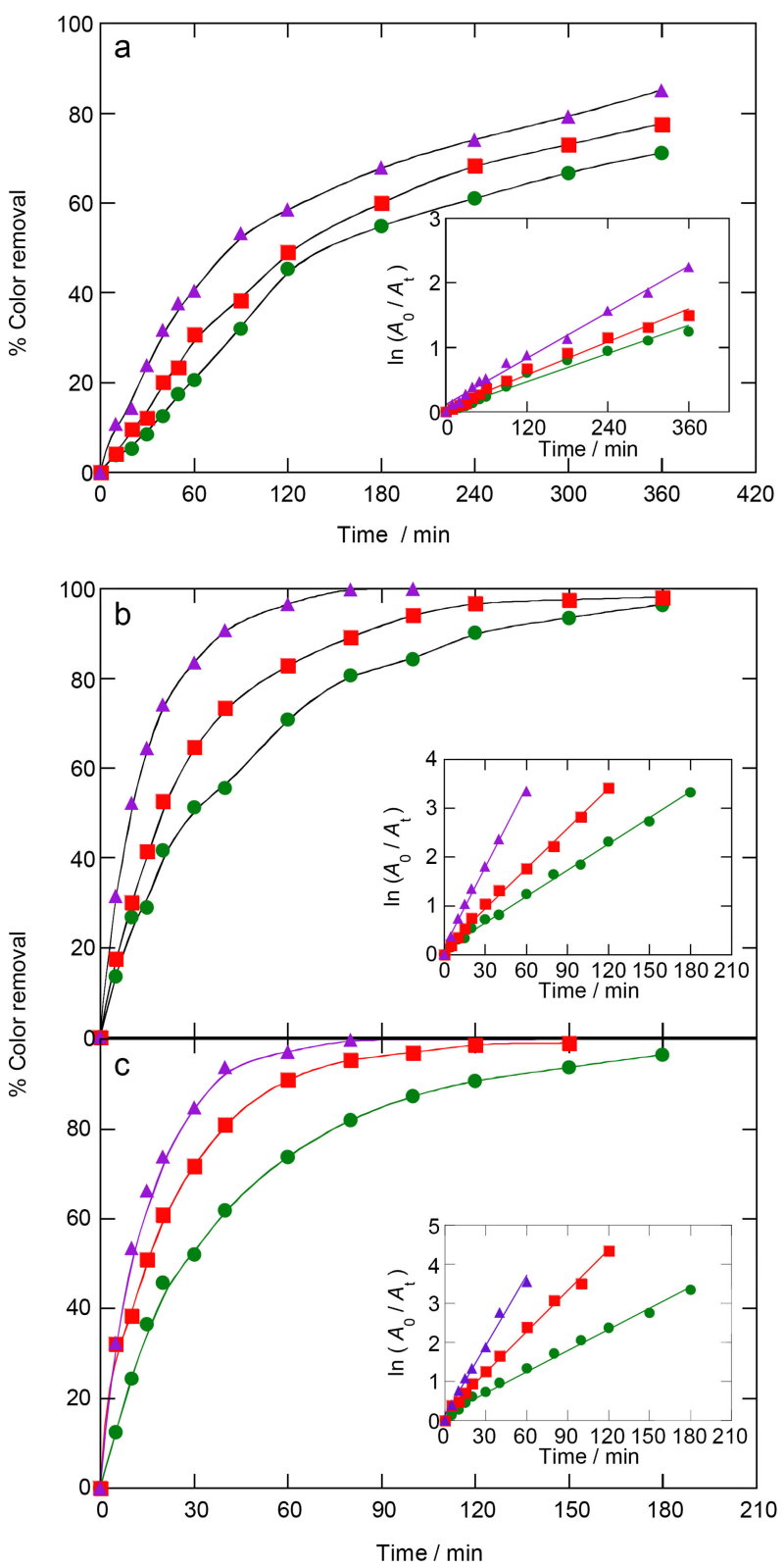

Figure 1. Decolorization efficiency vs. time for $2.5 \mathrm{~L}$ of $0.19 \mathrm{mM}$ PCSS solution in $0.050 \mathrm{M} \mathrm{Na}_{2} \mathrm{SO}_{4}$ at $\mathrm{pH} 3.0$ and $35^{\circ} \mathrm{C}$ using a pre-pilot flow plant with a Pt/air-diffusion cell by a) $\mathrm{AO}-\mathrm{H}_{2} \mathrm{O}_{2}$, b) $\mathrm{EF}$ with $0.50 \mathrm{mM} \mathrm{Fe}{ }^{2+}$, and c) PEF with $0.50 \mathrm{mM} \mathrm{Fe}^{2+}$. Current density: 25 (๑, green), 50 (ם, red), and $100 \mathrm{~mA} \mathrm{~cm}^{-2}$ ( $\boldsymbol{\Delta}$, violet). Insets: Kinetic analysis assuming a pseudo-firstorder decolorization reaction.

Figure 1a-c illustrates the change of percentage of color removal or decolorization efficiency for all these assays. This parameter was determined from the decay of absorbance $(A)$ at the $\lambda_{\max }=514 \mathrm{~nm}$ of Ponceau SS (Table 1 ) as follows: ${ }^{[28,34]}$

$\%$ Color removal $=\frac{A_{0}-A_{t}}{A_{0}} 100$

where $A_{0}$ denotes the initial absorbance and $A_{\mathrm{t}}$ that at time $t$. Two findings can be observed in Figure $1 a-c$. On the one hand, color removal was upgraded with increasing $j$, in agreement with the higher rate of reactions (1) and (2) that yield greater amounts of $\mathrm{H}_{2} \mathrm{O}_{2}$ and $\mathrm{Pt}\left({ }^{\circ} \mathrm{OH}\right)$, respectively, thus causing a quicker removal of the dye and its colored products. In addition, in EF and PEF the ${ }^{\circ} \mathrm{OH}$ production from Fenton's reaction (3) is accelerated by the rise of $\mathrm{H}_{2} \mathrm{O}_{2}$ content. On the other hand, it is evident that ${ }^{\circ} \mathrm{OH}$ generated in the latter two EAOPs decolorizes much more quickly the solution.

At $j=100 \mathrm{~mA} \mathrm{~cm}^{-2}$, for example, color was reduced by $85.1 \%$ after 360 min of $\mathrm{AO}-\mathrm{H}_{2} \mathrm{O}_{2}$, whereas the solution was completely decolorized at about 100 and 90 min in EF and PEF, respectively. This means that the decolorization power of EAOPs increased in the order: $\mathrm{AO}-\mathrm{H}_{2} \mathrm{O}_{2} \ll E F \leq$ PEF. The superiority of PEF over EF can be accounted for by the extra ${ }^{\circ} \mathrm{OH}$ generation provided by photolytic reaction (4).

To gain a better insight into the decolorization rate of the above assays, the absorbance decays were analyzed considering that they obeyed a pseudo-first-order kinetics. The excellent linear correlations obtained are presented in the insets of Figure $1 \mathrm{a}-\mathrm{c}$, and the slope corresponded to the decolorization rate constant $\left(k_{\mathrm{dec}}\right)$. The $k_{\mathrm{dec}}$-values thus found along with their $R^{2}$ are listed in Table 2. A look to this table corroborates the enhancement of $k_{\mathrm{dec}}$ as $j$ was increased in each treatment, as well as the faster loss of color attained by EF and PEF compared to $\mathrm{AO}-\mathrm{H}_{2} \mathrm{O}_{2}$. So, the $k_{\text {dec }}$-value was 9.2-fold and 10-fold higher for the two former processes at $j=100 \mathrm{~mA} \mathrm{~cm}^{-2}$. This confirms the important oxidation role of ${ }^{\circ} \mathrm{OH}$ in the bulk because it is able to quickly destroy high quantities of Ponceau SS and its colored products.

Figure $2 \mathrm{a}-\mathrm{c}$ depicts the TOC-time plots determined for the above tests. A progressive TOC removal along electrolysis time can be observed for each EAOP, which was enhanced when $j$ was increased, according to the greater amounts of hydroxyl radicals generated, as stated above. However, unlike decolorization, the percentage of TOC removal increased in the order: AO- $\mathrm{H}_{2} \mathrm{O}_{2}<\mathrm{EF}<\mathrm{PEF}$, with an evident rise for the PEF process due to the expected parallel photolysis of photoactive products upon UVA illumination, e.g., Fe(III)-carboxylate complexes via reaction (5). This tendency can also be deduced from the percentages of TOC removal collected in Table 2. As can be seen, the highest mineralization with $93.4 \%$ TOC reduction was achieved after $360 \mathrm{~min}$ of PEF at $j=100 \mathrm{~mA} \mathrm{~cm}^{-2}$, a value 1.6fold and 3.3-fold greater than those obtained for EF and AO$\mathrm{H}_{2} \mathrm{O}_{2}$, respectively. This means that the photolytic action of UVA light is much more relevant on the multiple organic intermediates than on the parent diazo dye.

The fate of $\mathrm{N}$ atoms contained in the Ponceau SS molecules $(0.76 \mathrm{mM})$ was followed during the PEF treatment at $j=$ $100 \mathrm{mAcm}^{-2}$. Neither $\mathrm{NO}_{2}{ }^{-}$nor $\mathrm{NO}_{3}{ }^{-}$ions were detected in the degraded solution, whereas $0.34 \mathrm{mM}$ of $\mathrm{NH}_{4}^{+}$(44.7\% of initial $\mathrm{N})$ were finally accumulated. These results suggest that the initial $\mathrm{N}$ was only mineralized to $\mathrm{NH}_{4}^{+}$ion and, based on the large degree of mineralization reached (93.4\%, Table 2), it can be suggested that part of the $\mathrm{N}$ was transformed into volatile $\mathrm{N}$-species, like $\mathrm{N}_{2}$ and $\mathrm{N}_{x} \mathrm{O}_{y}$, as suggested for other azo dyes. ${ }^{[34,42]}$ From this, the theoretical mineralization reaction for the anionic form of Ponceau SS, with $m=22 \mathrm{C}$ atoms and number of electrons $n=90$, can be expressed as follows: 


\begin{tabular}{|c|c|c|c|c|c|c|}
\hline Method & $\begin{array}{l}j \\
{\left[\mathrm{mAcm}^{-2}\right]}\end{array}$ & $\begin{array}{l}k_{\mathrm{dec}} \\
{\left[\mathrm{min}^{-1}\right]}\end{array}$ & $R^{2}$ & $\%$ TOC removal & $\% \mathrm{MCE}$ & $E C_{\mathrm{TOC}^{[a]}}$ \\
\hline \multicolumn{7}{|c|}{ Ti|Pt anode } \\
\hline \multirow{3}{*}{$\mathrm{AO}-\mathrm{H}_{2} \mathrm{O}_{2}$} & 25 & $3.7 \times 10^{-3}$ & 0,980 & 15.0 & 5.4 & 1.28 \\
\hline & 50 & $4.3 \times 10^{-3}$ & 0.984 & 23.9 & 4.5 & 2.62 \\
\hline & 100 & $6.0 \times 10^{-3}$ & 0.992 & 30.8 & 2.9 & 5.63 \\
\hline \multirow[t]{3}{*}{ EF } & 25 & $1.8 \times 10^{-2}$ & 0.996 & 42.2 & 16.1 & 0.45 \\
\hline & 50 & $2.7 \times 10^{-2}$ & 0.995 & 51.6 & 9.8 & 1.21 \\
\hline & 100 & $5.5 \times 10^{-2}$ & 0.994 & 60.0 & 5.7 & 3.04 \\
\hline \multirow[t]{3}{*}{ PEF } & 25 & $1.9 \times 10^{-2}$ & 0.992 & 72.6 & 27.6 & 10.8 \\
\hline & 50 & $3.5 \times 10^{-2}$ & 0.995 & 87.0 & 16.6 & 9.54 \\
\hline & 100 & $6.0 \times 10^{-2}$ & 0.989 & 93.4 & 8.9 & 10.1 \\
\hline \multicolumn{7}{|c|}{$B D D$ anode } \\
\hline \multirow[t]{3}{*}{$\mathrm{AO}-\mathrm{H}_{2} \mathrm{O}_{2}$} & 25 & $6.6 \times 10^{-3}$ & 0.982 & 48.8 & 18.6 & 0.64 \\
\hline & 50 & $9.7 \times 10^{-3}$ & 0.990 & 56.4 & 10.7 & 1.10 \\
\hline & 100 & $1.3 \times 10^{-2}$ & 0.981 & 65.0 & 6.2 & 2.74 \\
\hline \multirow[t]{3}{*}{ EF } & 25 & $2.3 \times 10^{-2}$ & 0.980 & 54.2 & 20.6 & 0.58 \\
\hline & 50 & $4.4 \times 10^{-2}$ & 0.992 & 63.0 & 12.0 & 1.37 \\
\hline & 100 & $6.5 \times 10^{-2}$ & 0.991 & 70.6 & 6.7 & 3.40 \\
\hline \multirow[t]{3}{*}{ PEF } & 25 & $2.6 \times 10^{-2}$ & 0.994 & 85.2 & 31.2 & 9.39 \\
\hline & 50 & $4.6 \times 10^{-2}$ & 0.994 & 93.8 & 16.9 & 9.11 \\
\hline & 100 & $8.7 \times 10^{-2}$ & 0.991 & 97.6 & 9.0 & 10.4 \\
\hline
\end{tabular}

$\mathrm{C}_{22} \mathrm{H}_{14} \mathrm{~N}_{4} \mathrm{O}_{7} \mathrm{~S}_{2}^{2}+45 \mathrm{H}_{2} \mathrm{O} \rightarrow$

$22 \mathrm{CO}_{2}+2 \mathrm{SO}_{4}{ }^{2-}+4 \mathrm{NH}_{4}^{+}+88 \mathrm{H}^{+}+90 \mathrm{e}^{-}(7)$

Considering this, the percentage of mineralization current efficiency (MCE) at time $t$ (in h) and applied current I (in A) for each run was calculated from reaction (8): ${ }^{[42]}$

$\% \mathrm{MCE}=\frac{n F V \Delta(\mathrm{TOC})_{\exp }}{4.32 \times 10^{7} \mathrm{~m} / t} 100$

where $F$ is the Faraday constant, $V$ is the solution volume (in L), $\Delta(\text { TOC) })_{\text {exp }}$ is the TOC removed (in $\mathrm{mg} \mathrm{L}^{-1}$ ) and $4.32 \times 10^{7}$ is a conversion factor $\left(=3,600 \mathrm{sh}^{-1} \times 12,000 \mathrm{mg} \mathrm{C} \mathrm{mol}^{-1}\right)$.

Figure S1a-c of Supporting Information shows the MCE profiles for the trials of Figure 2a-c. Small efficiencies were obtained in the $\mathrm{AO}-\mathrm{H}_{2} \mathrm{O}_{2}$ process due to its low mineralization ability. Figure S1a highlights that they were quite similar for $j$ values of 25 and $50 \mathrm{mAcm}^{-2}$, regularly decreasing for $j=$ $100 \mathrm{~mA} \mathrm{~cm}^{-2}$. This latter tendency was always observed for all the EF and PEF processes (Figure S1b and c, respectively), which can be ascribed to the progressive loss of organic matter with formation of more recalcitrant by-products. ${ }^{[12]}$ The MCE values listed in Table 2 after 360 min of electrolysis allows inferring that they decreased with increasing $j$ regardless of the method, reaching higher values according to its relative oxidation power. The most efficient treatment was PEF at $j=25 \mathrm{~mA} \mathrm{~cm}^{-2}$, with a maximal of $34.1 \%$ at $180 \mathrm{~min}$ that dropped to $27.6 \%$. The tendency of MCE with increasing $j$ was opposite to that of TOC, since the solution was more rapidly mineralized. This behavior is characteristic of EAOPs due to the larger enhancement of the parasitic (non-oxidizing) reactions of $\mathrm{Pt}\left({ }^{\circ} \mathrm{OH}\right.$ ) and ${ }^{\circ} \mathrm{OH}$ that reduce their relative concentration with the consequent loss of $\mathrm{MCE}^{[4,15]}$
Another figure of merit used to confirm the viability of EAOPs is the energy consumption. Based on the $\Delta(T O C)_{\exp }$ determined for each run and the corresponding cell voltage $\left(E_{\text {cell, }}\right.$ in $\left.\mathrm{V}\right)$, the energy consumption per unit TOC mass ( $\mathrm{EC}_{\mathrm{TOC}}$, in $\left.\mathrm{kWh}(\mathrm{gTOC})^{-1}\right)$ was calculated from Equation (9):[42,43]

$$
\mathrm{EC}_{\mathrm{TOC}}=\frac{E_{\text {cell }} / t}{V \Delta(\mathrm{TOC})_{\mathrm{exp}}}
$$

This equation is valid for $\mathrm{AO}-\mathrm{H}_{2} \mathrm{O}_{2}$ and $\mathrm{EF}$, as well as for SPEF because of the use of the free natural sunlight. For PEF, however, the electric power of the UVA lamp (160 W in our case) should be added, giving the alternative value of $\mathrm{EC}_{\text {Toc,total }}$ $\left(\mathrm{kWh}(\mathrm{gTOC})^{-1}\right)$, expressed as follows:

$\mathrm{EC}_{\mathrm{TOC}, \text { total }}=\frac{\left(E_{\text {cell }} l+160\right) t}{V \Delta(\mathrm{TOC})_{\exp }}$

Note that Equation (9) could also be used for PEF, assuming sunlight irradiation, i.e., the potential replacement of the UVA lamp by natural sunlight, as has been well proven experimentally elsewhere. ${ }^{[29,42,43]}$

As can be seen in Figure $\mathrm{S} 2 \mathrm{a}$ and $\mathrm{b}$, the $\mathrm{EC}_{\mathrm{TOC}}$ values for AO$\mathrm{H}_{2} \mathrm{O}_{2}$ and $\mathrm{EF}$ increased with increasing $j$ by the high rise of $E_{\text {cell, }}$ the opposite trend to that shown by MCE. This can be also deduced from the data collected in Table 2 at $360 \mathrm{~min}$ of both treatments. The lowest $\mathrm{EC}_{\text {Tос }}$ was achieved in $\mathrm{EF}$ at $j=$ $25 \mathrm{~mA} \mathrm{~cm}^{-2}$, slightly increasing from 0.34 to $0.45 \mathrm{kWh}$ (g TOC) $)^{-1}$ during the run. In the case of PEF, Figure S2c shows oscillating values for the enormous $E C_{\text {Tocitotal }}$ values determined with varying $j$ due to the compensation between the high electrical power of the UVA lamp and the greater TOC removal. They varied between 9.54 and $10.8 \mathrm{kWh}$ (g TOC) ${ }^{-1}$ (Table 2). Never- 


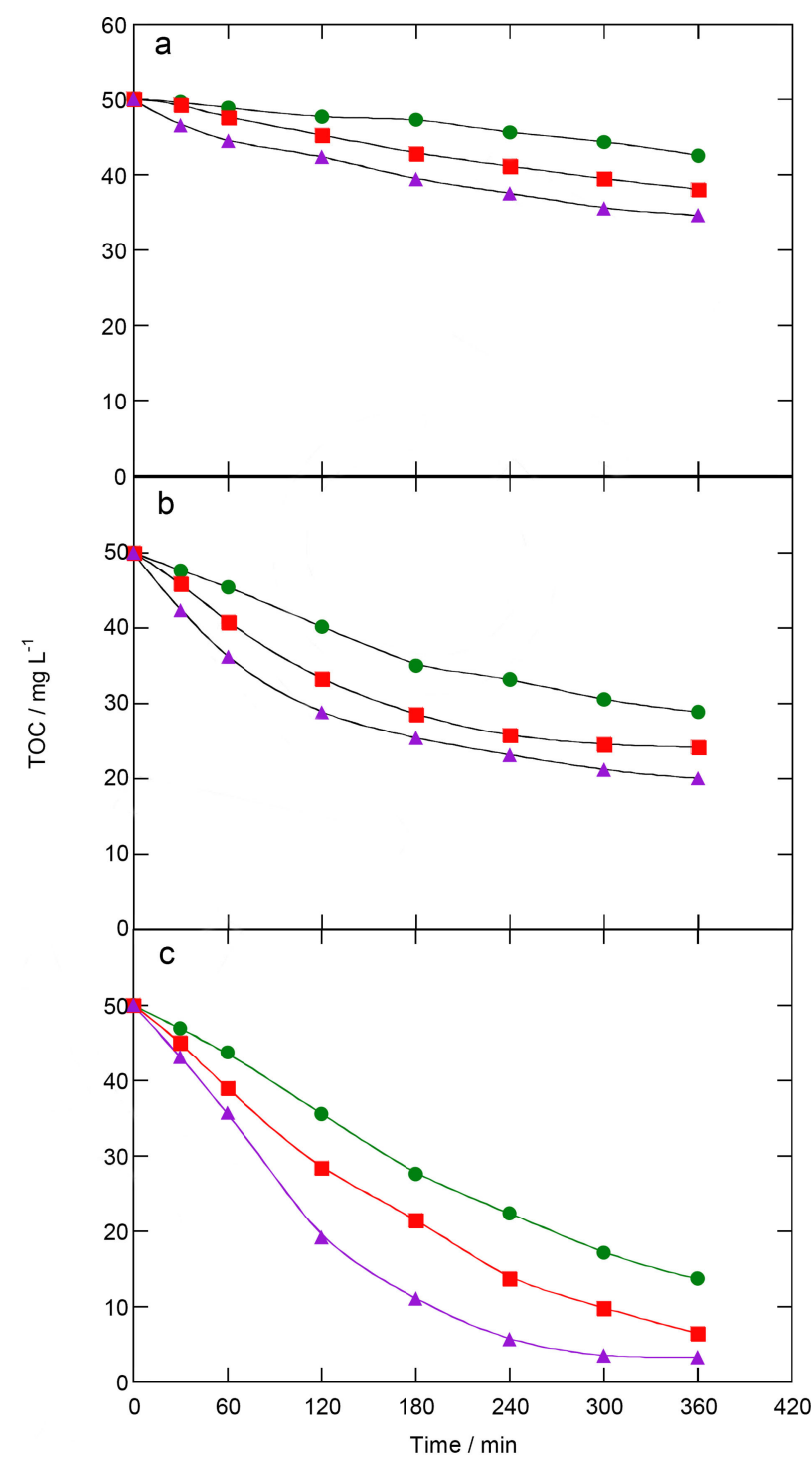

Figure 2. TOC decay with time for the trials of Figure 1 a) $A O-\mathrm{H}_{2} \mathrm{O}_{2}$, b) $\mathrm{EF}$, and c) PEF. Current density: 25 (O, green), $50\left(\mathbf{\square}\right.$, red), and $100 \mathrm{~mA} \mathrm{~cm}^{-2}(\mathbf{\Lambda}$, violet).

theless, the corresponding $\mathrm{EC}_{\text {Tос }}$ values at 360 min assuming no UVA power consumption decreased to $0.29 \mathrm{kWh}(\mathrm{gTOC})^{-1}$ at $j=$ $25 \mathrm{~mA} \mathrm{~cm}^{-2}$ and to $2.09 \mathrm{kWh}(\mathrm{gTOC})^{-1}$ at $j=100 \mathrm{mAcm}^{-2}$, which were much smaller than those obtained in EF. The aforementioned findings demonstrate a greater ability of PEF process to decolorize and mineralize the Ponceau SS solution as a result of the action of UVA radiation upon the photoactive intermediates originated by the attack of $\mathrm{Pt}\left({ }^{\bullet} \mathrm{OH}\right)$ and ${ }^{\bullet} \mathrm{OH}$.

\subsection{Degradation of Ponceau SS using a BDD Anode}

The study of the decolorization and mineralization of $2.5 \mathrm{~L}$ of $0.19 \mathrm{mM}$ Ponceau SS solutions in $0.050 \mathrm{M} \mathrm{Na}_{2} \mathrm{SO}_{4}$ at $\mathrm{pH} 3.0$ was extended to a $\mathrm{BDD} /$ air-diffusion cell in the pre-pilot flow plant under comparable conditions to those used with Pt. EF and PEF
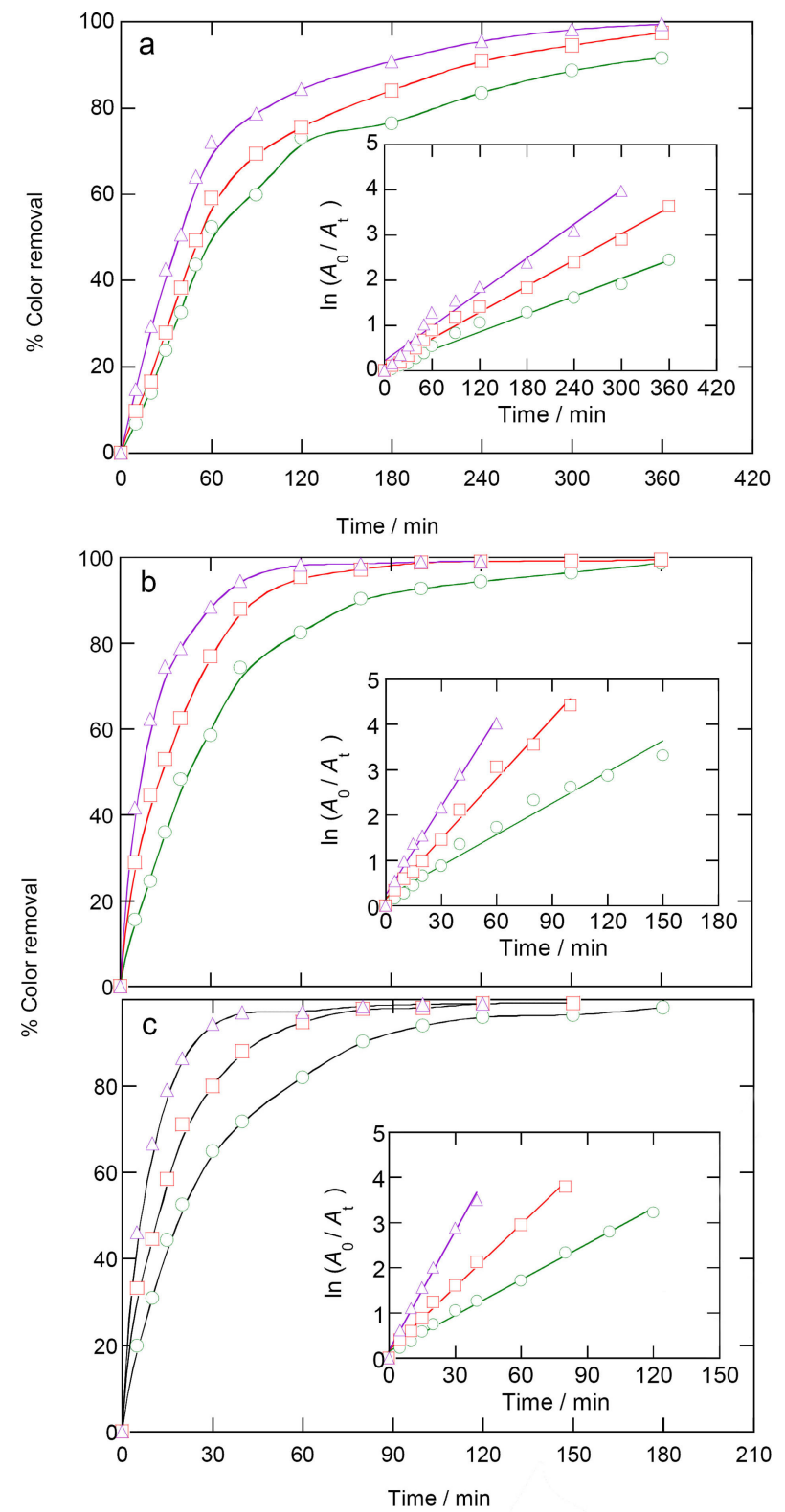

Figure 3. Change of percentage color removal for $2.5 \mathrm{~L}$ of $0.19 \mathrm{mM}$ PCSS solution in $0.050 \mathrm{M} \mathrm{Na}_{2} \mathrm{SO}_{4}$ at $\mathrm{pH} 3.0$ and $35^{\circ} \mathrm{C}$ using a pre-pilot flow plant with a BDD/air-diffusion cell by a) $\mathrm{AO}-\mathrm{H}_{2} \mathrm{O}_{2}$, b) EF, and c) PEF. Current density: 25 ( $\bigcirc$, green), 50 ( $\square$, red), and $100 \mathrm{~mA} \mathrm{~cm}^{-2}(\triangle$, violet). The insets present the analysis considering a pseudo-first-order decolorization kinetics.

were made with $0.50 \mathrm{mM} \mathrm{Fe}{ }^{2+}$. A slight decrease of the initial $\mathrm{pH}$ down to 2.6-2.7 was also found after $360 \mathrm{~min}$.

Figure $3 a-c$ illustrates the variation of color removal during the treatments carried out with a BDD anode. A progressively greater loss of color at higher $j$ can be observed for each method, associated with the concomitant larger generation of $\mathrm{BDD}\left({ }^{\circ} \mathrm{OH}\right)$ and/or ${ }^{\circ} \mathrm{OH}$ due to the increase in rate of reactions (1)-(3). The diazo dye solution was also decolorized much more quickly by EF and PEF compared to $\mathrm{AO}-\mathrm{H}_{2} \mathrm{O}_{2}$, thereby demonstrating the large oxidation enhancement of the target molecule and its colored products by ${ }^{\circ} \mathrm{OH}$ in the bulk. The insets of Figure $3 a-c$ show the excellent linear relationships 
obtained from a pseudo-first-order analysis of the corresponding absorbance drops. As expected, the resulting $k_{\mathrm{dec}}$-values, listed in Table 2, increased with increasing $j$ for each EAOP. Moreover, comparison of these constants confirmed a raising decolorization power in the order: $\mathrm{AO}-\mathrm{H}_{2} \mathrm{O}_{2} \ll \mathrm{EF}<\mathrm{PEF}$. Worth mentioning, the upgrade in ${ }^{\circ} \mathrm{OH}$ production from photolytic reaction (4) accounts for the decolorization enhancement in PEF compared to EF. On the other hand, an inspection of Table 2 allows inferring the greater $k_{\mathrm{dec}}$-values found in all cases with BDD compared to those obtained with Pt. While $k_{\text {dec }}$ was 1.8-2.2 fold higher in $\mathrm{AO}-\mathrm{H}_{2} \mathrm{O}_{2}$, it underwent a smaller grew of 1.2-1.5-fold in EF and PEF. The remarkable rise in decolorization rate in the former EAOP using a non-active BDD anode agrees with the expected greater oxidation ability of $\operatorname{BDD}\left({ }^{\circ} \mathrm{OH}\right) .^{[4,12,31]}$ The parallel effective oxidation with ${ }^{\bullet} \mathrm{OH}$ explains the smaller contribution of the above physisorbed radicals in the two Fenton-based EAOPs.

The TOC-time plots depicted in Figure $4 a-c$ using a BDD anode, along with the percentage of TOC removal given in Table 2, evidence a faster mineralization in the sequence: $\mathrm{AO}$ $\mathrm{H}_{2} \mathrm{O}_{2}<\mathrm{EF}<$ PEF. This is in agreement with the decolorization behavior pointed out above and the results obtained with a $\mathrm{Ti} \mid \mathrm{Pt}$ anode. This corroborates the increasing role of $\mathrm{BDD}\left({ }^{\circ} \mathrm{OH}\right),{ }^{\bullet} \mathrm{OH}$ and UVA light to destroy organic pollutants leading to the above relative oxidation power of EAOPs. Figure $4 a-c$ and Table 2 also confirm the greater mineralization achieved for each method when $j$ was increased from 25 to $100 \mathrm{mAcm}^{-2}$, as expected by the larger production of reactive $\mathrm{BDD}\left({ }^{\circ} \mathrm{OH}\right)$ and/or ${ }^{\circ} \mathrm{OH}$. It is remarkable the considerable growth of mineralization in $\mathrm{AO}-\mathrm{H}_{2} \mathrm{O}_{2}$ when using BDD instead of Pt; for example, $65.0 \%$ vs. $30.8 \%$ TOC reduction at $360 \mathrm{~min}$ of $j=100 \mathrm{~mA} \mathrm{~cm}^{-2}$ (Table 2). This difference was less significant in $\mathrm{EF}(70.6 \%$ vs. $60.0 \%)$ due to the important oxidation via ${ }^{\circ} \mathrm{OH}$ in the bulk, and only a minimum difference was found in PEF (97.6\% vs. 93.4\%) as a result of UVA irradiation.

These findings point to a clear superiority of BDD to be used in the $\mathrm{AO}-\mathrm{H}_{2} \mathrm{O}_{2}$ and EF treatment of Ponceau SS solutions, being much less evident in PEF, particularly at high $j$ values, where a large mineralization with $>93 \%$ TOC abatement can be reached (Figure $2 \mathrm{c}$ and $4 \mathrm{c}$ ).

The MCE values at 360 min (Table 2) showed a gradual drop with increasing $j$ for each EAOP, as expected by the progressive larger extent of the parasitic reactions. ${ }^{[14,15,42]}$ The relative oxidation ability of BDD anode grew in the order: $\mathrm{AO}-\mathrm{H}_{2} \mathrm{O}_{2}<$ $\mathrm{EF}<\mathrm{PEF}$, as for Pt. Comparison of the MCE data for both anodes confirms the much higher efficiency achieved using the former anode in $\mathrm{AO}^{-} \mathrm{H}_{2} \mathrm{O}_{2}$ (e.g., $6.2 \%$ vs. $2.9 \%$ at $100 \mathrm{mAcm}{ }^{-2}$ ). This difference was strongly reduced in $\mathrm{EF}(6.7 \%$ vs. $5.7 \%$ at the same $j$ ), whereas in PEF, the same mineralization current efficiencies were practically obtained at $50 \mathrm{mAcm}^{-2}(16.6 \%-$ $16.9 \%)$ and $100 \mathrm{mAcm}^{-2}$ (8.9-9.0\%). Regarding the $\mathrm{EC}_{\text {TOC }}$ values in $\mathrm{AO}-\mathrm{H}_{2} \mathrm{O}_{2}$ and $\mathrm{EF}$ with BDD of Table 2, they increased with $j$ and were significantly lower than those obtained with $\mathrm{Pt}$, despite the higher $E_{\text {cell }}$ of the BDD/air-diffusion cell due to the larger mineralization reached. In contrast, the $\mathrm{EC}_{\mathrm{TOC}, \text { total }}$ values determined in PEF varied between 9.1 and $10.4 \mathrm{kWh}(\mathrm{gTOC})^{-1}$, quite analogous to those found for Pt because of the very large contribution of the lamp power. When this contribution was

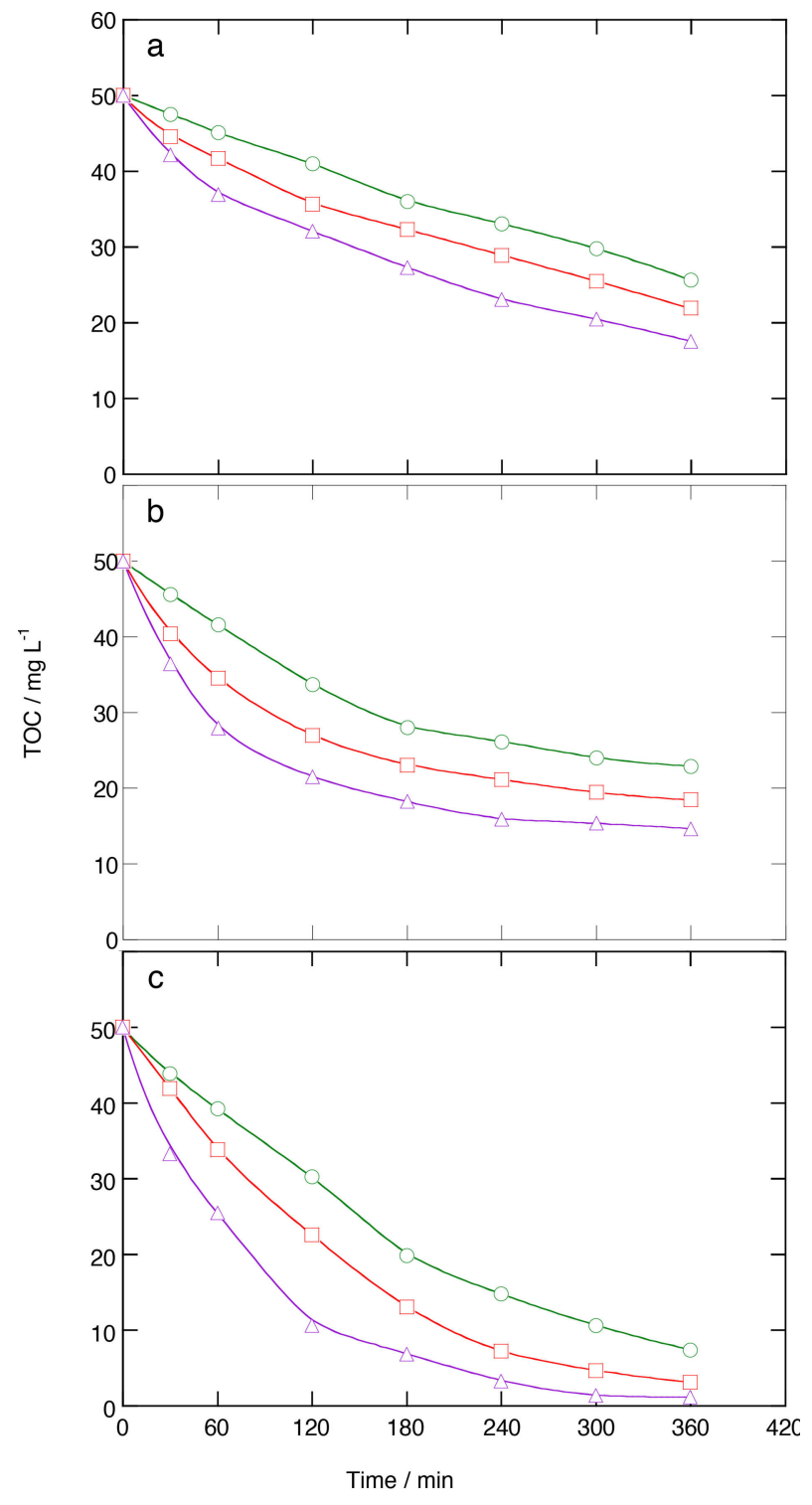

Figure 4. TOC abatement for the assays of Figure 3 a) $\left.A O-\mathrm{H}_{2} \mathrm{O}_{2}, \mathrm{~b}\right) \mathrm{EF}$, and c) PEF. Current density: $25\left(\bigcirc\right.$, green), $50\left(\square\right.$, red), and $100 \mathrm{~mA} \mathrm{~cm}^{-2}(\triangle$, violet).

not considered, the $\mathrm{EC}_{\mathrm{TOC}}$ values were $0.37,0.97$, and $2.46 \mathrm{kWh}$ $\left(\mathrm{gTOC}^{-1}\right.$ at 25,50 , and $100 \mathrm{mAcm}^{-2}$, respectively, which are much greater than in the case of Pt (see section 2.1).

The study performed for the degradation of Ponceau SS in the pre-pilot flow plant with a cell containing an air-diffusion electrode indicates that the BDD anode is preferable in $\mathrm{AO}$ $\mathrm{H}_{2} \mathrm{O}_{2}$ and $\mathrm{EF}$, because it provides faster decolorization and TOC reduction, with higher $\mathrm{MCE}$ and lower $\mathrm{EC}_{\mathrm{TOC}}$. Under $\mathrm{PEF}$ conditions at $j \geq 50 \mathrm{mAcm}^{-2}$, however, both anodes showed a quite similar degradation performance.

\subsection{Detection of Oxidation Products using a Pt Anode}

Five primary aromatic products formed during the PEF degradation of a $0.19 \mathrm{mM}$ Ponceau SS solution in the pre-pilot plant with a Ti $\mid \mathrm{Pt}$ anode at $j=50 \mathrm{mAcm}^{-2}$ were identified by 
GC-MS. They were 2 azo derivatives and 3 benzenic products, which were also found in $\mathrm{AO}-\mathrm{H}_{2} \mathrm{O}_{2}$ and $\mathrm{EF}$, as well as in all EAOPs using BDD, since they arise from the attack of hydroxyl radicals (generated in all cases) onto the initial dye. On this basis, Scheme 1 proposes a reaction sequence for the primary

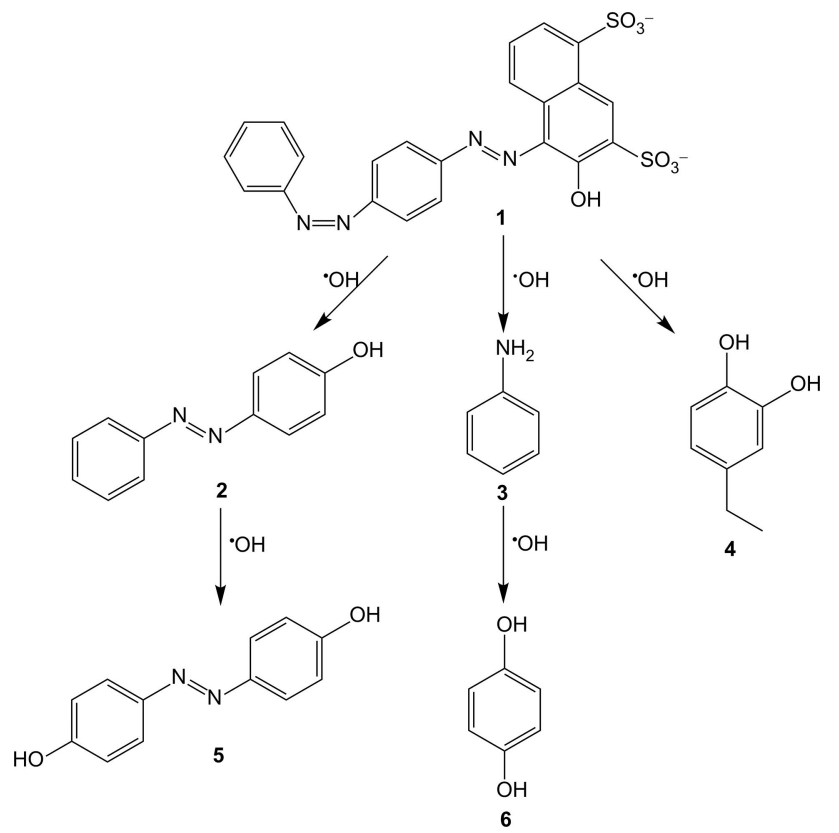

Scheme 1. Proposed initial route for the degradation of Ponceau SS diazo dye by EAOPs. ${ }^{\circ} \mathrm{OH}$ represents the hydroxyl radical formed at the anode surface from water oxidation and in the bulk from Fenton's reaction.

degradation of Ponceau SS (1) involving such radicals as main oxidants. This pathway highlights that the initial hydroxylation of 1 leads to the cleavage of either one azo group leading to 4(phenylazo)phenol (2) and aniline (3), or part of its naphthalenic ring originating 4-ethyl-1,2-benzenediol (4). Further hydroxylation of $\mathbf{2}$ yields the hydroxylated di-(4-hydroxy-phenyl)diazene (5), whereas that of $\mathbf{3}$ gives hydroquinone (6).

It is well known that the subsequent destruction of the above aromatics leads to short-chain aliphatic carboxylic acids, which form Fe(III) complexes under PEF conditions. ${ }^{[1-45]} \mathrm{A}$ mixture of oxalic, tartronic, malic, and acetic acids was detected for the above assay by ion-exclusion HPLC. Figure 5 illustrates the evolution of these acids during the treatment. Total removal of Fe(III)-oxalate, $\mathrm{Fe}$ (III)-tartronate and Fe(III)-acetate complexes was achieved at the end of the electrolysis, pre-eminently due to their photolysis via reaction (5) since such Fe(III)-carboxylate were very poorly abated by $\mathrm{Pt}\left({ }^{\bullet} \mathrm{OH}\right)$ and ${ }^{\bullet} \mathrm{OH} .{ }^{[14,15]}$ In contrast, $\mathrm{Fe}(\mathrm{III})$-malate complexes were more slowly degraded and $13.0 \mathrm{mgL}^{-1}$ of malic acid remained in the final solution, representing $3.5 \mathrm{mg} \mathrm{L}^{-1}$ TOC that corresponds to $26.9 \%$ of the organic load (13.0 $\mathrm{mg} \mathrm{L}^{-1}$ as deduced from Table 2 ). This can be explained by the formation of a larger proportion of other recalcitrant undetected products that can be more rapidly removed by increasing $j$ or using a BDD anode because of the higher oxidation power of $\mathrm{BDD}\left({ }^{\circ} \mathrm{OH}\right)$.

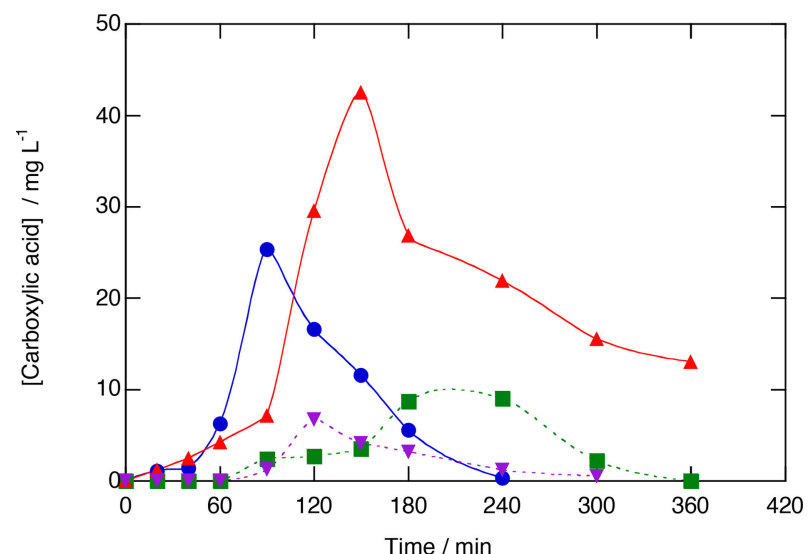

Figure 5. Time-course of the concentration of oxalic ( $)$, blue), tartronic ( green), malic $(\boldsymbol{\Lambda}$, red), and acetic ( $\boldsymbol{\nabla}$, violet) acids detected during the PEF degradation of $2.5 \mathrm{~L}$ of $0.19 \mathrm{mM}$ Ponceau SS solution in $0.050 \mathrm{M} \mathrm{Na}_{2} \mathrm{SO}_{4}$ at $\mathrm{pH} 3.0$ using a pre-pilot flow plant with a Pt/air-diffusion cell at $50 \mathrm{~mA} \mathrm{~cm}^{-2}$,

\section{Conclusions}

It has been shown that $2.5 \mathrm{~L}$ of a $0.19 \mathrm{mM}$ Ponceau SS solution in acidic sulfate medium treated a pre-pilot flow plant by AO$\mathrm{H}_{2} \mathrm{O}_{2}$ and $\mathrm{EF}$ were more quickly decolorized and mineralized using a BDD/air-diffusion cell. This is due to the much greater oxidation ability of $\mathrm{BDD}\left({ }^{\circ} \mathrm{OH}\right)$ compared to $\mathrm{Pt}\left({ }^{\circ} \mathrm{OH}\right)$, partially compensated by the parallel oxidation by ${ }^{\circ} \mathrm{OH}$ produced from Fenton's reaction in EF. PEF was the most powerful EAOP thanks to the additional potent photolytic action of UVA radiation, leading to a quite similar decolorization and mineralization rate for both cells. In all cases, the decolorization decay obeyed a pseudo-first-order kinetics, with increasing $k_{\text {dec }}$-values with raising $j$. The same trend was found for TOC abatement, with loss of mineralization current efficiency and increase of the energy consumption. High $\mathrm{EC}_{\mathrm{TOC} \text {,total }}$ values were obtained in PEF taking into account the lamp power, but the corresponding consumption if lamp power was not considered was lower than those of AO- $\mathrm{H}_{2} \mathrm{O}_{2}$ and EF. The use of an active anode to destroy the diazo dye by photo-assisted Fenton-based EAOPs is thus recommended, whereas the non-active $B D D$ results more useful in $\mathrm{AO}-\mathrm{H}_{2} \mathrm{O}_{2}$ and EF. Five primary aromatic products and four final carboxylic acids were detected.

\section{Experimental Section}

Ponceau SS $(80 \%$ purity, and the rest of components were stabilizing salts) was purchased from Sigma-Aldrich. Sulfuric acid ( $96 \%$ purity) from Acros Organics and analytical grade $\mathrm{NaOH}$ from Panreac were used to adjust $\mathrm{pH}$ conditions. All the solutions were prepared with deionized water. The rest of chemicals including $\mathrm{Na}_{2} \mathrm{SO}_{4}$ and $\mathrm{FeSO}_{4} \cdot 7 \mathrm{H}_{2} \mathrm{O}$ used as background electrolyte and catalyst, respectively, were of analytical or HPLC grade purchased from Fluka, Merck, Panreac and Sigma-Aldrich.

Electrochemical assays were carried out in a $2.5 \mathrm{~L}$ pre-pilot flow plant composed of the following consecutive elements: ${ }^{[45]}$ (i) a PVC reservoir containing the solution; (ii) a centrifugal pump to recirculate the solution through the system; (iii) a rotameter to 
regulate the liquid flow rate at $200 \mathrm{Lh}^{-1}$; (iv) two heat exchangers to maintain the solution temperature at $35^{\circ} \mathrm{C}$; (v) a filter-press electrochemical cell equipped with a BDD thin-film on $\mathrm{Si}$ (NeoCoat) or a Ti $\mid$ Pt (NMT) anode and a carbon-PTFE air-diffusion cathode (Sainergy Fuel Cell), all with $20 \mathrm{~cm}^{2}$ of geometric area in contact with the solution and separated $1.2 \mathrm{~cm}$; and (vi) an annular SchottDuran glass photoreactor containing $640 \mathrm{~mL}$ of solution volume. Atmospheric air at overpressure of $8.6 \mathrm{kPa}$ was injected to the dry face of the cathode for $\mathrm{H}_{2} \mathrm{O}_{2}$ production. The plant was covered with an opaque cloth for $\mathrm{AO}-\mathrm{H}_{2} \mathrm{O}_{2}$ and EF trials, whereas a Philips $160 \mathrm{~W}$ UVA lamp $\left(\lambda_{\max }=360 \mathrm{~nm}\right)$ was centered in the annular photoreactor for PEF. Galvanostatic electrolyses were performed with a Grelco GVD310 (0-10 A) power supply, which displayed directly the cell voltage $\left(E_{\text {cell }}\right)$.

A Crison GLP22 pH-meter was used to measure the $\mathrm{pH}$ of solutions. Prior to analysis, all the samples were filtered with Whatman $0.45 \mu \mathrm{m}$ PTFE filters. In EF and PEF, they were previously alkalinized to stop the degradation. The loss of solution color was determined from the absorbance decay at $\lambda_{\max }=514 \mathrm{~nm}$ using a Shimadzu $1800 \mathrm{UV} / \mathrm{vis}$ spectrophotometer. The same equipment was utilized for the determination of $\mathrm{H}_{2} \mathrm{O}_{2}$ from its Ti(IV) complex. ${ }^{[46]}$ TOC was measured on a Shimadzu TOC-VCSN analyzer, by injecting $50 \mu \mathrm{L}$ aliquots and with a precision of $\pm 1 \%$. Average values $( \pm 2 \%$ values) are reported for replicated decolorization and TOC measurements.

lon-exclusion HPLC analysis was performed by injecting $10 \mu \mathrm{L}$ into a Waters system (600 LC and 996 photodiode array detector at $\lambda=$ $210 \mathrm{~nm}$ ) using an Aminex HPX 87H, $300 \mathrm{~mm} \times 7.8 \mathrm{~mm}$, column at $35^{\circ} \mathrm{C}$ from Bio-Rad and eluting $4 \mathrm{mM} \mathrm{H}_{2} \mathrm{SO}_{4}$ solution at $0.6 \mathrm{~mL}$ $\mathrm{min}^{-1}$. Retention times of $6.7,7.7,9.6$ and $15.2 \mathrm{~min}$ for oxalic, tartronic, malic and acetic acids, respectively, were found. $\mathrm{NH}_{4}{ }^{+}$ concentration was obtained from the standard phenate method. ${ }^{477]}$ GC-MS analysis was made after extraction with $\mathrm{CH}_{2} \mathrm{Cl}_{2}(3 \times 25 \mathrm{~mL})$ of the organic components of $100 \mathrm{~mL}$ of solutions treated during short times by PEF using a Pt/air-diffusion cell, followed by drying the resulting organic solution with $\mathrm{Na}_{2} \mathrm{SO}_{4}$, filtration and volume reduction. An Agilent system with a non-polar J\&W HP-5 ms $0.25 \mu \mathrm{m}, 30 \mathrm{~m} \times 0.25 \mathrm{~mm}$, column, was utilized as reported previously. ${ }^{[30]}$ The products were identified with the help of a NIST05 MS library.

\section{Acknowledgements}

Authors acknowledge support from project CTQ2016-78616- $R$ (AEI/FEDER, EU) and projects CNPq - 465571/2014-0; CNPq 446846/2014-7 and CNPq - 401519/2014-7T (National Council for Scientific and Technological Development, Brazil). A. J. dos Santos gratefully acknowledges the PhD grant awarded from CAPES and "doutorado sanduiche" under the Program PDSE-CAPES 88881.133501/2016-01.

\section{Conflict of Interest}

The authors declare no conflict of interest.

Keywords: anodic oxidation - electrochemistry • electroFenton - photocatalysis - Ponceau SS dye

\section{References}

[1] T. Robinson, G. McMullan, R. Marchant, P. Nigam, Biores. Technol. 2001, $77,247-255$.

[2] H. Zollinger, Color Chemistry: Synthesis, Properties, and Applications of Organic Dyes and Pigments, VHCA and Wiley-VCH, Switzerland, 2003.

[3] V. Khandegar, A. K. Saroha, J. Environ. Manage. 2013, 128, 949-963.

[4] E. Brillas, C. A. Martínez-Huitle, Appl. Catal. B: Environ. 2015, 166-167, 603-643.

[5] UNESCO, The United Nations World Water Development Report 4, Vol. 1: Managing Water Report under Uncertainty and Risk, 2012.

[6] E. Forgacs, T. Cserháti, G. Oros, Environ. Int. 2004, 30, 953-971.

[7] A. B. dos Santos, F. J. Cervantes, J. B. van Lier, Biores. Technol. 2007, 98, 2369-2385.

[8] S. M. A. G. Ulson de Souza, E. Forgiarini, A. A. Ulson de Souza, J. Hazard. Mater. 2007, 147, 1073-1078.

[9] K. P. Sharma, S. Sharma, S. P. Sharma, K. Singh, S. Kumar, R. Grover, P. K. Sharma, Chemosphere 2007, 69, 48-54.

[10] R. Sanghi, B. Bhattacharya, Water Qual. Res. J. Can. 2003, 38, 553-562.

[11] A. K. Verma, R. R. Dash, P. Bhunia, J. Environ. Manage. 2012, 93, 154-168.

[12] M. Panizza, G. Cerisola, Chem. Rev. 2009, 109, 6541-6569.

[13] A. Anglada, A. Urtiaga, I. Ortiz, J. Chem. Technol. Biotechnol. 2009, 84, 1747-1755.

[14] I. Sirés, E. Brillas, Environ. Int. 2012, 40, 212-229.

[15] I. Sirés, E. Brillas, M. A. Oturan, M. A. Rodrigo, M. Panizza, Environ. Sci. Pollut. Res. 2014, 21, 8336-8367.

[16] E. Tsantaki, T. Velegraki, A. Katsaounis, D. Mantzavinos, J. Hazard. Mater. 2012, 207-208, 91-96.

[17] M. B. Ferreira, J. H. B. Rocha, J. V. de Melo, C. A. Martínez-Huitle, M. A. Quiroz Alfaro, Electrocatalysis 2013, 4, 274-282.

[18] M. A. Quiroz, J. L. Sánchez-Salas, S. Reyna, E. R. Bandala, J. M. PeraltaHernández, C. A. Martínez-Huitle, J. Hazard. Mater. 2014, 268, 6-13.

[19] A. Thiam, I. Sirés, J. A. Garrido, R. M. Rodríguez, E. Brillas, Sep. Purif. Technol. 2015, 140, 43-52.

[20] M. Rivera, M. Pazos, M. A. Sanromán, Desalination 2011, 274, 39-43.

[21] M. Panizza, M. A. Oturan, Electrochim. Acta 2011, 56, 7084-7087.

[22] N. Daneshvar, S. Aber, V. Vatanpour, M. H. Rasoulifard, J. Electroanal. Chem. 2008, 615, 165-174.

[23] M. S. Yahya, N. Oturan, K. El Kacemi, M. El Karbane, C. T. Aravindakumar, M. A. Oturan, Chemosphere 2014, 117, 447-454.

[24] F. Sopaj, M. A. Rodrigo, N. Oturan, F. I. Podvorica, J. Pinson, M. A. Oturan, Chem. Eng. J. 2015, 262, 286-294.

[25] P. A. Diaw, N. Oturan, M. D. Gaye-Seye, A. Coly, A. Tine, J.-J. Aaron, M. A. Oturan, Sep. Purif. Technol. 2017, 186, 197-206.

[26] A. Khataee, A. Khataee, M. Fathinia, B. Vahid, S. W. Joo, J. Ind. Eng. Chem. 2013, 19, 1890-1894.

[27] A. Khataee, A. Akbarpour, B. Vahid, J. Taiwan Inst. Chem. Eng. 2014, 45, 930-936.

[28] X. Florenza, A. M. S. Solano, F. Centellas, C. A. Martínez-Huitle, E. Brillas, S. Garcia-Segura, Electrochim. Acta 2014, 142, 276-288.

[29] A. Thiam, I. Sirés, F. Centellas, P. L. Cabot, E. Brillas, Chemosphere 2015, $136,1-8$.

[30] J. R. Steter, E. Brillas, I. Sirés, Electrochim. Acta 2016, 222, 1464-1474.

[31] B. Marselli, J. García-Gomez, P. A. Michaud, M. A. Rodrigo, C. Comninellis, J. Electrochem. Soc. 2003, 150, D79-D83.

[32] A. Kapałka, G. Fóti, C. Comninellis, Electrochim. Acta 2009, 54, 20182023.

[33] J. H. Bezerra Rocha, M. M. Soares Gomes, E. Vieira dos Santos, E. C. Martins de Moura, D. Ribeiro da Silva, M. A. Quiroz, C. A. MartínezHuitle, Electrochim. Acta 2014, 140, 419-426.

[34] S. Garcia-Segura, F. Centellas, C. Arias, J. A. Garrido, R. M. Rodríguez, P. L. Cabot, E. Brillas, Electrochim. Acta 2011, 58, 303-311.

[35] A. Bedolla-Guzman, I. Sirés, A. Thiam, J. M. Peralta-Hernández. S. Gutiérrez-Granados, E. Brillas, Electrochim. Acta 2016, 206, 307-316.

[36] K. Cruz-González, O. Torres-López, A. García-León, J. L. Guzmán-Mar, L. H. Reyes, A. Hernández-Ramírez, J. M. Peralta-Hernández, Chem. Eng. J. 2010, 160, 199-206.

[37] L. Feng, E. D. Van Hullebusch, M. A. Rodrigo, G. Esposito, M. A. Oturan, Chem. Eng. J. 2013, 228, 944-964.

[38] M. A. Oturan, J.-J. Aaron, Crit. Rev. Environ. Sci. Technol. 2014, 23, 25772641.

[39] A. Wang, J. Qu, H. Liu, J. Ru, Appl. Catal. B: Environ. 2008, 84, 393-399.

[40] V. S. Antonin, S. Garcia-Segura, M. C. Santos, E. Brillas, J. Electroanal. Chem. 2015, 747, 1-11. 
[41] A. M. S. Solano, C. A. Martínez-Huitle, S. Garcia-Segura, A. El-Ghenymy, E. Brillas, Electrochim. Acta 2016, 197, 210-220.

[42] E. J. Ruiz, A. Hernández-Ramírez, J. M. Peralta-Hernández, C. Arias, E. Brillas, Chem. Eng. J. 2011, 171, 385-392

[43] F. C. Moreira, S. Garcia-Segura, V. J. P. Vilar, R. A. R. Boaventura, E. Brillas, Appl. Catal. B: Environ. 2013, 142-143, 877-890.

[44] G. Coria, I. Sirés, E. Brillas, J. L. Nava, Chem. Eng. J. 2016, 304, 817-825.

[45] C. Flox, J. A. Garrido, R. M. Rodríguez, P. L. Cabot, F. Centellas, C. Arias, E. Brillas, Catal. Today 2007, 127, 29-36.

[46] F. J. Welcher, Standard Methods of Chemical Analysis, 6th ed, Vol. 2, Part B, R. E. Krieger Publishing Co, Huntington, New York, 1975.
[47] A. D. Eaton, L. S. Clesceri, A. E. Greenberg, Standard Methods for the Examination of Water and Wastewater, 22nd ed, APHA, AWWA, WEF, 2012.

Manuscript received: November 20, 2017

Accepted Article published: December 4, 2017

Version of record online:

\section{These are not the final page numbers! $\lambda$}




\section{ARTICLES}

Degradation of Ponceau SS dye: Similar decolorization and mineralization rates are obtained with photoelectro-Fenton by using a pre-pilot flow plant with a BDD/air-difffusion or Pt/air-diffusion cell. Initially, five aromatic products are formed, followed by their conversion into four carboxylic acids, which are transformed into carbon dioxide (see figure).

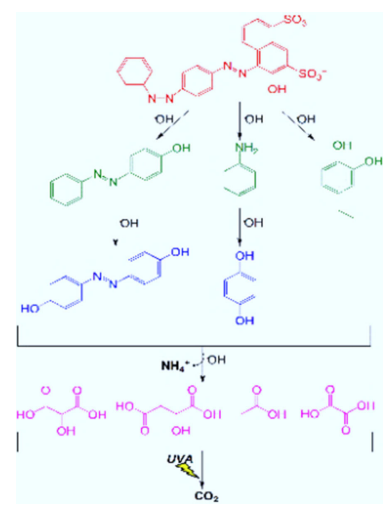

A. J. dos Santos, Prof. C. A. MartínezHuitle, Prof. I. Sirés, Prof. E. Brillas*

$1-10$

Use of Pt and Boron-Doped Diamond Anodes in the Electrochemical Advanced Oxidation of Ponceau SS Diazo Dye in Acidic Sulfate Medium 